\title{
Heritability of susceptibility to Salmonella enteritidis infection in fowls and test of the role of the chromosome carrying the NRAMPl gene
}

\author{
Odile Girard-Santosuosso ${ }^{a}$, Frédéric Lantier ${ }^{a *}$, \\ Isabelle LANTIER ${ }^{\mathrm{a}}$, Nat BUMSTEAD ${ }^{\mathrm{b}}$, Jean-Michel ELSEN ${ }^{\mathrm{c}}$, \\ Catherine BeAumont ${ }^{\mathrm{d}}$ \\ a Département de santé animale, Station de pathologie infectieuse et immunologie, \\ Institut national de la recherche agronomique, 37380 Nouzilly, France \\ ${ }^{\mathrm{b}}$ Compton laboratory, Institute for Animal Health, Compton, \\ Newbury, Berkshire, BBSRC, G20 7NN, UK \\ ${ }^{\mathrm{c}}$ Département de génétique animale, Station d'amélioration génétique des animaux, \\ Institut national de la recherche agronomique, 31326 Castanet-Tolosan, France \\ ${ }^{\mathrm{d}}$ Département de génétique animale, Station de recherches avicoles, \\ Institut national de la recherche agronomique, 37380 Nouzilly, France
}

(Received 15 March 2001; accepted 5 November 2001)

\begin{abstract}
- 373 thirteen-week-old chicks issued from a commercial cross and 312 chickens from the L2 line were intravenously inoculated with $10^{6}$ Salmonella enteritidis and the numbers of Salmonella in the spleen, liver and genital organs were assessed 3 days later. Heritabilities of the number of Salmonella were estimated at $0.02 \pm 0.04$ and $0.05 \pm 0.05$ in the liver; at $0.29 \pm 0.07$ and $0.10 \pm 0.06$ in the spleen; and at $0.16 \pm 0.05$ and $0.11 \pm 0.08$ in the genital organs, in the first and second experiments, respectively. The difference between the two experiments could result from sampling variations and from differences in the genetic structure of the two populations possibly including both heterosis and additive effects as well as their interaction in the first experiment. Genetic correlations between the number of bacteria in the genital organs and liver ( $0.56 \pm 0.58$ and $0.76 \pm 0.32$ in the first and second experiments, respectively) and spleen $(0.37 \pm 0.24$ and $0.79 \pm 0.23)$ were positive. Moreover a significant within-sire effect of VIL1, a marker gene for $N R A M P 1$, was observed in 117 progeny resulting from 25 informative matings. These results indicate that there are genetic differences in the resistance to visceral infection by $S$. enteritidis in these commercial egg-laying flocks, and suggest that these differences are at least partly due to genetic polymorphism in the NRAMP1 region.
\end{abstract}

\section{genetics / Salmonella / resistance / NRAMP1 / poultry}

\footnotetext{
* Correspondence and reprints

E-mail: lantier@tours.inra.fr
} 


\section{INTRODUCTION}

Salmonella contamination is a major source of toxic infections in humans, often through poultry products [5]. Since Salmonella are ubiquitous, such contamination is very difficult to prevent, moreover carriers (i.e. animals that remain contaminated several weeks after contamination without evident signs of infection) can disseminate the bacteria to other chickens or to human beings. Increasing the resistance of animals could potentially circumvent this problem, especially in preventing or reducing the extent of the carrier-state. Recently, Berthelot et al. [2] and Beaumont et al. [1] showed that resistance of fowls to the carrier-state is heritable: the heritability $\left(h^{2}\right)$ was estimated at 0.20 when chickens were inoculated at one week of age and at 0.38 when hens were inoculated at the peak of lay. Selecting resistant birds on the basis of this criterion would however require much work and considerable expense because the carrier state has to be measured over several weeks. Identifying the underlying genes controlling resistance could make it possible to select without the costs and difficulties involved in exposure to infection. In mice, the NRAMPI and TLR4 genes have been widely studied; the first is responsible for enhanced intracellular killing of bacteria by macrophages and the latter is involved in the response to bacterial lipopolysaccharide, an abundant component of the bacterial membrane of Gram-negative bacteria, including Salmonella. $\mathrm{Hu}$ et al. [12] showed that these genes also partly control susceptibility, assessed as mortality after intramuscular inoculation, of day-old chicks. These results were however obtained in very young animals while the main risk of Salmonella to humans is due to the consumption of meat or contaminated eggs from adult animals. Large differences in susceptibility have been observed between poultry lines following inoculation at the peak of lay [14] or a little earlier, at 13 weeks of age [9]. The latter inoculation protocol is easier to perform because animals are younger and intravenous inoculation is more repeatable.

The goal of this work was to estimate the heritability of resistance for fowls inoculated intravenously at 13 weeks of age, and to test the effect of NRAMP1 on this trait using two markers for this gene: the villin 1 (VILI) gene and the microsatellite marker $A D L 111$.

\section{MATERIALS AND METHODS}

\subsection{Chickens}

All animals were egg-type chickens. In the first experiment, a commercial egg-type cross was used and 373 chickens were inoculated. These animals were progeny of 19 sires and 29 dams (i.e. a maximum of 2 dams per sire with the exception of one sire mated to 3 dams); in the second experiment, 312 animals were studied. They originated from the L2 line described in [9], which 
is a parent of the commercial cross and were derived from 29 sires mated to a maximum of 4 dams (i.e. a total of 89 dams). In experiment 1 and 2, all animals hatched on the same day and were reared in 4 and 3 rooms respectively. All eggs were from pathogen free flocks known to be free of Salmonella, and were hatched and reared at the "station de recherches avicoles" until 12 weeks of age.

\subsection{Bacteria}

Strain 1009 of $S$. enteritidis PT4, which is resistant to nalidixic acid (Nal) and streptomycin (Sm), was used for the two trials as described in $[1,2,6,9,11$, 14].

\subsection{Preparation of the inoculum}

S. enteritidis strain 1009 was grown in trypticase soy broth (BioMérieux, France) overnight at $37^{\circ} \mathrm{C}$ with shaking at $200 \mathrm{rpm}$ [9]. The bacterial suspension was adjusted to a concentration of $10^{9}$ colony forming units (CFU) per $\mathrm{mL}$ by appropriate dilutions in PBS containing glycerol (10\%) and was stored at $-70^{\circ} \mathrm{C}$. On the inoculation day, the bacterial suspension was diluted in sterile PBS to obtain an inoculum concentration of $2.5 \times 10^{6} \mathrm{CFU} \cdot \mathrm{mL}^{-1}$. This concentration was confirmed by plating on TSA medium supplemented with antibiotics, $\mathrm{Nal}\left(100 \mu \mathrm{g} \cdot \mathrm{mL}^{-1}\right)$ and $\mathrm{Sm}\left(500 \mu \mathrm{g} \cdot \mathrm{mL}^{-1}\right)$.

\subsection{Challenge and necropsy}

In the two experiments, 373 (Expt. 1) or 312 (Expt. 2) thirteen-week-old chickens were intravenously inoculated into a wing vein with $0.4 \mathrm{~mL}$ of the inoculum containing $10^{6} \mathrm{CFU}$. Necropsies were performed three days postinoculation on three batches of randomly sampled animals.

\subsection{Bacterial enumeration in organs}

Livers, spleens and genital organs were aseptically removed from the chickens (with the exception of the genital organs of 52 chickens from the first experiment). The CFU of $S$. enteritidis per gram were determined as described in [9] and the numbers of $S$. enteritidis per organ were calculated from bacterial counts and organ weight values.

Salmonella could be found in the three organs of all animals except in the genital organs of 57 and 84 chicks in the first and second experiment respectively and in the livers of 35 animals in the first one. The organs whose levels of contamination were very small (less than the mean level minus three standard deviations) were considered as missing, which was the case of four and three spleens in the first and second experiments respectively. 


\subsection{Estimation of genetic parameters}

The heritability and genetic correlations of the number of bacteria per organ for the liver, spleen and genital organs were estimated using REML (REStricted Maximum Likelihood) and an animal model with VCE4 software [10]. The model of analysis included the fixed effect of the room and the random effects of the individual. Phenotypic correlations were computed from the sums of estimated animal and residual variance-covariance components.

\subsection{PvuII PCR polymorphism at the VIL1 locus}

Detection of polymorphism for the Villin gene by PvuII digestion of PCR products was carried out as described in [7]. The size of the VIL1 PCR amplified fragment from the genomic DNA was $760 \mathrm{bp}$. $P v u I I$ digestion of the amplified fragment revealed three recognition sites, one of which was polymorphic with fragments of $130 \mathrm{bp}$ (allele a) or $190 \mathrm{bp}$ (allele b). PvuII-digested fragments of 290, 280, 130 and $60 \mathrm{bp}$ and $P v u I I-d i g e s t e d$ fragments of 290, 280 and $190 \mathrm{bp}$ were defined as genotypes aa and bb, respectively.

\section{8. $A D L 111$ microsatellite marker}

The ADL 111 microsatellite was isolated [3]. The sequence of the $A D L 111$ microsatellite repeat was $(\mathrm{TG})_{15}\left(\mathrm{~T}_{4} \mathrm{G}\right)_{5} \mathrm{~T}_{7}$ (GenBank accession number G01724; [4]). Polymerase chain reaction primers and conditions are described in [4]. The PCR reactions were analysed using an ABI 373A DNA Sequencer with a $6 \%$ polyacrylamide gel. Genescan 672 software was used to determine the sizes of the PCR products.

\subsection{Statistical analysis}

Within-sire effects of the VILI and $A D L 111$ markers on the number of $S$. enteritidis in the liver, spleen and genital organs were tested by analysis of variance using SAS software [15].

\section{RESULTS AND DISCUSSION}

\subsection{Elementary statistics}

Means, standard-deviations and the range of variation of the number of Salmonella per organ are shown in Table I. Some differences were observed between experiments which may be partly due to the different genetic origins of the animals (a cross in the first experiment and a pure line in the second one). But in both cases, the level of contamination was much higher in the 
Table I. Elementary statistics of the number of Salmonella per spleen, liver and genital organs in the two experiments (noted Exp1 and Exp2). CFU, coloning-forming units; SE, Salmonella enteritidis.

\begin{tabular}{|c|c|c|c|c|c|c|}
\hline & \multicolumn{2}{|c|}{$\begin{array}{c}\log _{10} \text { CFU of SE } \\
\text { per liver }\end{array}$} & \multicolumn{2}{|c|}{$\begin{array}{c}\log _{10} \mathrm{CFU} \text { of SE } \\
\text { per spleen }\end{array}$} & \multicolumn{2}{|c|}{$\begin{array}{l}\log _{10} \mathrm{CFU} \text { of } \mathrm{SE} \\
\text { per genital organs }\end{array}$} \\
\hline & Exp1 & Exp2 & Exp1 & Exp2 & Exp1 & Exp2 \\
\hline Mean & 3.76 & 3.95 & 5.36 & 5.63 & 1.13 & 1.56 \\
\hline Standard-error & 0.65 & 0.83 & 0.38 & 0.48 & 0.76 & 0.69 \\
\hline Minimal value $^{(1)}$ & 2.03 & 1.95 & 4.05 & 4.01 & -0.54 & 0.3 \\
\hline Maximal value & 6.05 & 7.20 & 6.24 & 6.93 & 4.29 & 3.78 \\
\hline
\end{tabular}

(1) Among contaminated organs.

spleen and liver than in the genital organs, as formerly observed after an oral inoculation in [14].

Correlations between the logarithms of the number of Salmonella per organ and of the number of Salmonella per gram of organ were very high since the range of variation is much lower for the organ weight than for the number of CFU. In the first experiment they were estimated at $0.99,0.98$ and 0.91 for the spleen, liver and genital organs respectively. Since human and animal contamination depends more on the total number of bacteria than on concentration (number of CFU per gram of organ), only the results on the former traits are shown.

\subsection{Estimated heritabilities of the presence of $S$. enteritidis in the liver, spleen and genital organs}

See Tables II and III. Heritabilities for the number of Salmonella were estimated as $0.02 \pm 0.04$ and $0.05 \pm 0.05$ for the liver; $0.29 \pm 0.07$ and $0.10 \pm 0.06$ for the spleen; and $0.16 \pm 0.05$ and $0.11 \pm 0.08$ for the genital organs for the two experiments. In the spleen, the estimated heritability was higher in commercial chickens (Expt. 1) than in the L2 line (Expt. 2), while heritability estimates for the liver and genital organs differed to a lesser extent. These differences could result from sampling variation since the size of both data sets were rather small, because of the huge amount of work needed for such measures. They may also be due to the different genetic origins of the birds, since heritability depends on the population [13], also possibly resulting from dominance effects segregating in a cross but not in a pure line (which is the case for the first and second populations, respectively). The parameters estimated within in the L2 line therefore appear to be more reliable, since heritability estimated in a pure line only depends on additive effects. In both cases, the heritabilities of the number of bacteria in the spleen and genital organs strongly suggest genetic 
Table II. Genetic parameters of traits estimated in commercial chickens (logarithms of CFU of Salmonella enteritidis (SE) in the liver, spleen and genital organs). Heritabilities are on the diagonal, genetic and phenotypic correlations are above and under the diagonal respectively.

\begin{tabular}{lccc}
\hline & $\begin{array}{c}\log _{10} \text { CFU of SE } \\
\text { per liver }\end{array}$ & $\begin{array}{c}\log _{10} \text { CFU of SE } \\
\text { per spleen }\end{array}$ & $\begin{array}{c}\log _{10} \text { CFU of SE } \\
\text { per genital organs }\end{array}$ \\
\hline $\begin{array}{l}\log _{10} \text { CFU of SE } \\
\text { per liver }\end{array}$ & $0.02 \pm 0.04$ & $-0.03 \pm 0.43$ & $0.56 \pm 0.58$ \\
$\begin{array}{l}\log _{10} \text { CFU of SE } \\
\text { per spleen }\end{array}$ & 0.21 & $0.29 \pm 0.07$ & $0.37 \pm 0.24$ \\
$\begin{array}{l}\log _{10} \text { CFU of SE } \\
\text { per genital organs }\end{array}$ & 0.26 & 0.14 & $0.16 \pm 0.05$ \\
\hline
\end{tabular}

Table III. Genetic parameters of traits estimated in L2 chickens (logarithms of CFU of Salmonella enteritidis in the liver, spleen and genital organs). Heritabilities are on the diagonal, genetic and phenotypic correlations are above and under the diagonal respectively.

\begin{tabular}{lccc}
\hline & $\begin{array}{c}\log _{10} \text { CFU of SE } \\
\text { per liver }\end{array}$ & $\begin{array}{c}\log _{10} \text { CFU of SE } \\
\text { per spleen }\end{array}$ & $\begin{array}{c}\log _{10} \text { CFU of SE } \\
\text { per genital organs }\end{array}$ \\
\hline $\begin{array}{l}\log _{10} \text { CFU of SE } \\
\text { per liver }\end{array}$ & $0.05 \pm 0.05$ & $0.19 \pm 0.56$ & $0.76 \pm 0.32$ \\
$\begin{array}{l}\log _{10} \text { CFU of SE } \\
\text { per spleen }\end{array}$ & 0.49 & $0.10 \pm 0.06$ & $0.79 \pm 0.23$ \\
$\begin{array}{l}\text { Log } \\
\text { per } \text { genital of SE }\end{array}$ & 0.59 & 0.40 & $0.11 \pm 0.08$ \\
\hline
\end{tabular}

inheritance in the incidence of the contamination of these organs as early as 3 days after intravenous inoculation of the 13-week-old chickens.

Genetic correlations between the number of bacteria in the liver and genital organs $(0.56 \pm 0.58$ and $0.76 \pm 0.32$ in the first and second experiments, respectively) were high, which suggests that most of the genes controlling contamination of these two organs are the same. A positive but slightly smaller genetic correlation was also observed between the numbers of $S$. enteritidis in the spleen and genital organs $(0.37 \pm 0.24$ and $0.79 \pm 0.23$ in the first and second experiments, respectively). The genetic correlations between the number of bacteria in the liver and in the spleen were very low $(-0.03 \pm 0.43$ and $0.19 \pm 0.56 \mathrm{in}$ first and second experiments respectively). Although both organs become infected in systemic infections, their kinetics of contamination are different [9] and it appears that their levels of contamination may be controlled by different genes. 
Table IV. Within-sire effect of NRAMP1 markers (VIL1 gene and ADL 111 microsatellite) on the number of $S$. enteritidis in the liver, spleen and genital organs.

\begin{tabular}{lccc}
\hline NRAMP1 markers & Liver & Spleen & Genital organs \\
\hline VIL1 & $0.007^{*}$ & $0.005^{*}$ & 0.38 \\
ADL 111 & 0.33 & 0.10 & 0.21 \\
\hline
\end{tabular}

* Significant $(p<0.01)$ within-sire effect of NRAMP1 markers.

These estimated heritabilities suggest that a decrease in the risk of human infection could be achieved through selection for a lower level of contamination of genital organs. The genetic correlations between the numbers of bacteria in the genital organs and other organs indicate such selection would also result in a decrease in the level of contamination of other visceral organs.

\subsection{Within-sire effect of NRAMP1 markers (VIL1 gene and ADL 111 microsatellite) on the number of $S$. enteritidis in the liver, spleen and genital organs}

The within-sire effect of the VIL1 marker could only be studied for informative animals, i.e. on the offspring of heterozygous sires whose paternal origin of VIL1 alleles could be assessed, i.e. on 73 progeny issued from 10 sires and a total of 25 females. The within-sire effect of the VIL1 gene on the number of $S$. enteritidis is shown in Table IV. It was significant in the liver $(p<0.007)$ and in the spleen $(p<0.005)$ but not in the genital organs $(p=0.38)$. The coefficient of determination of the model was only significant $(p<0.05)$ when the effect of the marker gene was included in the analysis. The VIL1 gene has been mapped to the NRAMPl linkage group C9, which corresponds to chromosome 7 [8] and the genetic distance between NRAMP1 and VIL1 estimated at only $2.6 \mathrm{cM}$. The proximity of VIL1 to NRAMPI suggests that the NRAMPl gene, or the chromosome region carrying the NRAMPl gene, is involved in the control of the genetic resistance of $S$. enteritidis infection in these two organs (liver and spleen), as in mice [16].

The within-sire effect of the $A D L 111$ microsatellite was studied on 152 progeny which were issued from 17 heterozygous males and a total of 56 females (Tab. IV). It approached significance only in the spleen $(p<0.10)$. However the distance between $A D L 111$ and the NRAMP1 gene is larger $(20 \mathrm{cM})$ and probably explains the lack of association between this marker and bacterial levels.

Further investigation is needed to estimate the efficiency of marker-assisted selection for creating a poultry line genetically resistant to $S$. enteritidis. It 
should also be possible to estimate whether selection for decreased contamination of the spleen and liver 3 days after intravenous inoculation of 13-week-old chickens would reduce the risk of ovarian contamination in adult chickens.

\section{ACKNOWLEDGEMENTS}

The authors wish to acknowledge the breeding units of the Station de recherches avicoles and Station de pathologie infectieuse et immunité. They are indebted to R. Delaunay, D. Musset, W. Piémont and P. Bernardet for animal care and practical assistance during necropsies. O. Girard-Santosuosso is indebted to F. Lacroix, for technical assistance; to N. Millet and A. Boucard for practical assistance. This work was supported by the EEC project "Genetic strategies toward control of foodborne salmonellosis".

\section{REFERENCES}

[1] Beaumont C., Protais J., Guillot J.F., Colin P., Proux K., Millet N., Pardon P., Genetic resistance to mortality of day-old chicks and carrier-state of hens after inoculation with Salmonella enteritidis, Avian Pathol. 28 (1999) 131-135.

[2] Berthelot F., Beaumont C., Mompart F., Girard-Santosuosso O., Pardon P., Duchet-Suchaux M., Estimated heritability of the resistance to cecal carrier state of Salmonella enteritidis in chickens, Poultry Sci. 77 (1998) 797-801.

[3] Cheng H.H., Crittenden L.B., Microsatellite markers for genetic mapping in the chicken, Poultry Sci. 73 (1994) 539-546.

[4] Cheng H.H., Levin I., Vallejo R.L., Khatib H., Dodgson J.B., Crittenden L.B., Hillel J., Development of a genetic map of the chicken with markers of high utility, Poultry Sci. 74 (1995) 1855-1874.

[5] Desenclos J.C., Bouvet P., Pierre V., Brisabois A., Fremy S., Lahellec C., Grimont F., Grimont P.A.D., Épidémiologie des infections à Salmonella: tendances récentes en France et en Europe, Bull. Soc. Fr. Microbiol. 11 (1996) 209-215.

[6] Duchet-Suchaux M., Mompart F., Berthelot F., Beaumont C., Léchopier P., Pardon P., Differences in frequency, level and duration of cecal carriage between four outbred chicken lines infected orally with Salmonella enteritidis, Avian Dis. 41 (1997) 559-567.

[7] Girard-Santosuosso O., Lantier I., Millet N., Mouline C., Guillot J.F., Protais J., Colin P., Beaumont C., Lantier F., PvuII PCR polymorphism at the chicken VIL locus, Anim. Gen. 27 (1996) 371-383.

[8] Girard-Santosuosso O., Bumstead N., Lantier I., Protais J., Colin P., Guillot J.F., Beaumont C., Malo D., Lantier F., Partial conservation of the mammalian NRAMP1 syntenic group on chicken chromosome 7, Mamm Genome 8 (1997) 614-616.

[9] Girard-Santosuosso O., Menanteau P., Duchet-Suchaux M., Berthelot F., Mompart F., Protais J., Colin P., Guillot J.F., Beaumont C., Lantier F., Variability in the resistance of four chicken lines to experimental intravenous infection with Salmonella enteritidis phage type 4, Avian Dis. 42 (1998) 462-469. 
[10] Groeneveld E., VCE4 User's guide and manual (1997).

[11] Guillot J.F., Beaumont C., Bellatif F., Mouline C., Lantier F., Colin P., Protais J., Comparison of resistance of various poultry lines to infection by Salmonella enteritidis, Vet. Res. 26 (1995) 81-86.

[12] Hu J., Bumstead N., Barrow P., Sebastiani G., Olien L., Morgan K., Malo D., Resistance to salmonellosis in the chicken is linked to NRAMPI and TNC, Genome Res. 7 (1997) 693-704.

[13] Ollivier L., Éléments de génétique quantitative, Masson, Paris, 1981.

[14] Protais J., Colin P., Beaumont C., Guillot J.F., Lantier F., Pardon P., Bennejean G., Line differences in resistance to Salmonella enteritidis PT4 infection, Br. Poultry Sci. 37 (1996) 329-339.

[15] SAS Institute Inc., SAS/STAT ${ }^{\circledR}$ User's guide, version 6, 4th edn., Cary NC, SAS Institute Inc., (1989).

[16] Swanson R.N., O'Brien A.D., Genetic control of the innate resistance of mice to Salmonella typhimurium: Ity gene is expressed in vivo by 24 hours after infection, J. Immunol. 131 (1983) 3014-3020.

To access this journal online: www.edpsciences.org 